NOTED:

\section{Moral quandary over social and political use of mobile phones}

The Moral Economy of Mobile Phones: Pacific Islands Perspectives, edited by Robert J. Foster and Heather A. Horst. Canberra: ANU Press, 2018. 163 pages. ISBN 978-1-76046208-6 (print); 978-1-7604-6209-3 (e-book)

W HILE anthropologists have mainly studied mobile phone use at an individual or group level, the entry of Digicel into Pacific nations' mobile markets over the past decade has introduced a wider set of issues that are explored here in detail.

Robert Foster details the tradeoffs of managing mobile phone credits and airtime in Papua New Guinea, showing how airtime credits and reduced calling rate promotions influence the ways people conduct their relationships and maintain social networks.

Holly Wardlow's chapter on mobile phone use in HIV treatment highlights not just how technology offers new approaches to treatment, but also the complex moral territory of "phone friend' relationships, which offer support and safety through what often amounts to fantasy or deception.

Dan Jorgensen describes Toby, who claims mobile phones are a conspiracy to bring US surveillance to Papua New Guinea; yet, the mobile network once saved his life when he was stuck in the mountains without shelter and close to death.

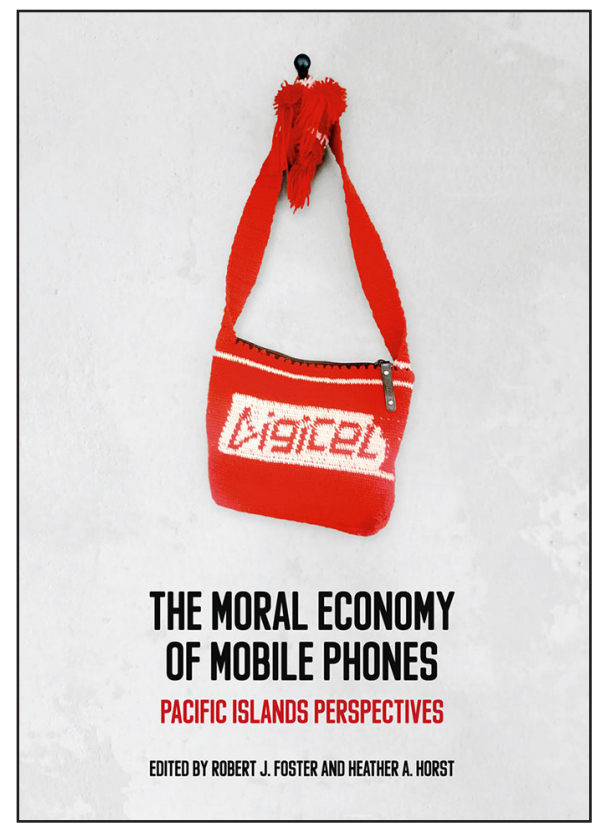

While deep ambivalence towards the adoption of digital technologies is nothing new, the moral element of these analyses in their Pacific contexts is striking, particularly where tensions between use and misuse and questions of social and political power are involved. - Dr Christopher Thomson, co-director, Arts Digital Lab, University of Canterbury, Christchurch, New Zealand.

\section{E-Tangata-getting it right}

The Best of e-Tangata, edited by Tapu Misa and Gary Wilson. Wellington: Bridget Williams, 2017. 208 pages. ISBN 978-0-9475-1845-5

$T$ HE BEST of e-Tangata is a collection of pieces from the online site (https:/e-tangata.co.nz/) that offer insights into the lives of Māori and Pasifika people in Aoteoroa. Some of their 


\section{The Best of e-Tangata}

\section{EDITED BY TAPU MISA AND GARY WILSON}

'STORIES HELP US MAKE SENSE OF WHO WE ARE AND WHO WE WANT TO BE'

\section{BWB Texts}

stories are quite harrowing, like that of Gilbert Enoka, who was raised in a series of homes after his father abandoned his disabled mother

Others, like that of Naida Glavish, are almost beyond belief today. Glavish — real first name Rangimarie — was threatened with the sack from the Post office in the 1980s for answering the phone with 'kia ora'.

Others verge on the surreal, like the story of Ngapuhi kaumatua Kingi Taura, who was told by his school teacher to choose a Pākeha name and decided to name himself Albert, after the family rooster.

Eliota Fuimaono-Saolu talks about his attempt to rectify what he considers to be the distortion of Pacific history in New Zealand schools by producing a DVD that told a very different story about the peoples of the great ocean.

Of great interest, too, is the interview with former Prime Minister Jim Bolger, who talks about the Treaty and settlement issues and concludes that the lesson he had learned from working with Māori on the Treaty process was that the important issue was 'getting it right'.-Dr PHILIP CASS is reviews editor of Pacific Journalism Review.

\section{New Zealand's future is Pacific}

Island Time: New Zealand's Pacific Futures, by Damon Salesa. Wellington: Bridget Williams, 2017. 256 pages. ISBN978-1-9885-3353-7G.

PEOPLE occasionally claim that Auckland has the largest Islander population in the world. While that claim is manifestly untrue-Port Moresby clearly takes that crown-Auckland's demographics are changing. As Toeolesulusulu Damon Salesa points out in this fascinating book, Pasifika are the wave of the future.

Political parties have begun to recognise the potential of Pasifika voters and there is a lengthy section on the growth of Pasifika people as a political force and he argues that forcing political parties to pay attention to them has actually made New Zealand politics better.

Pasifika voters have usually supported Labour and he traces the attempts of other parties to woo them away, including a disastrous attempt by the Māori Party to run Pasifika candidates against 